\title{
Effect of Abiotic Factors on the Populations of Pod Borer, Helicoverpa armigera (Hubner) on Marigold, Tagetes erecta in Jammu, India
}

\author{
Suheel Ahmad Ganai*, Hafeez Ahmad, Devinder Sharma, Nadeya Khaliq, \\ Sonika Sharma, Ramandeep Kaur and Thanlass Norboo
}

Block No. 6, Division of Entomology, FoA Main Campus, SKUAST-J, Chatha, Jammu -180 009, J\&K, India

*Corresponding author

\begin{tabular}{|c|c|}
\hline & A B S T R A C T \\
\hline Keywords & \multirow{5}{*}{$\begin{array}{l}\text { The results of the investigation on population dynamics of pod borer } \\
\text { (Helicoverpa armigera Hubner) in relation to abiotic factors revealed that } \\
\text { the pest commenced from } 7^{\text {th }} \text { standard week, which remained till } 18^{\text {th }} \\
\text { standard week with its peak activity during } 15^{\text {th }} \text { standard week. The } \\
\text { correlation studies indicated highly significant positive association between } \\
\text { larval population of } H \text {. armigera and mean maximum temperature } \\
\left(0.349^{*}\right) \text { and highly significant negative association between } H \text {. armigera } \\
\text { and mean relative humidity (morning) }\left(-0.284^{*}\right) \text {. The non-significant } \\
\text { effect was observed between larval population of } H \text {. armigera and mean } \\
\text { relative humidity (evening) (-0.256) and mean rainfall (-0.174). Mean } \\
\text { minimum temperature had significant effect on the } H \text {. armigera population } \\
(0.404) \text {. }\end{array}$} \\
\hline $\begin{array}{l}\text { Helicoverpa } \\
\text { armigera, Tagetes } \\
\text { erecta, Population } \\
\text { dynamics, }\end{array}$ & \\
\hline $\begin{array}{l}\text { Correlation, } \\
\text { Abiotic factors. }\end{array}$ & \\
\hline Article Info & \\
\hline $\begin{array}{l}\text { Accepted: } \\
\text { 04 July } 2017 \\
\text { Available Online: } \\
\text { 10 September } 2017\end{array}$ & \\
\hline
\end{tabular}

\section{Introduction}

Helicoverpa armigera Hubner (Lepidoptera: Noctuidae), the cotton bollworm, also known as the gram pod borer or the tomato fruit worm, is a polyphagous agricultural pest with a wide geographical distribution, recorded from Europe, Asia, Africa, Oceania, and recently South America. Larvae of $H$. armigera have been reported from over 67 host families, including Asteraceae, Fabaceae, Malvaceae, Poaceae and Solanaceae and this pest has caused losses to economically important crops such as cotton, legumes, sorghum, maize, tomato, soybean, ornamental plants, and fruit trees (Krinski and Godoy, 2015). Marigold (Tagetes spp.) (Asterals: Asteraceae), a native of Mexico, is one of the most popular cut flowers in the world having the highest economic importance in the floriculture industry and comprises about 33 species (Adriana et al., 2012).

The area under floriculture production in India during the year 2015-2016 was estimated to be as 243 thousand hectares with a production of 2236 thousand matric tonnes (Anonymous, 2016). Among the various 
factors responsible for low yield of marigold in India, $H$. armigera is most important, which cause very heavy losses in yield. Excessive use of chemicals not only causes the economic restrain on farmers, but also produces the harmful side effects on the environments as well as mammals.

The best way to overcome this situation is to destroy the pest at initial stage of the life cycle (Chatar et al., 2010). This is possible if timely prediction of the incidence of the pest can be made. Hence, an attempt was made to investigate the incidence of pod borer, $H$. armigera infesting marigold in relation to different abiotic factors.

\section{Materials and Methods}

The effect of abiotic factors on fluctuation in population of pod borer, $H$. armigera was carried out on marigold variety "Pusa Narangi Gainda" for two consecutive years (2014 and 2015) at University Farm, Sher-e-Kashmir University of Agricultural Sciences and Technology of Jammu.

The crop was raised with recommended agronomic practices in the plot size of $3 \times 1 \mathrm{~m}$ with row to row and plant to plant distance of $45 \mathrm{~cm}$ and $20 \mathrm{~cm}$, respectively. Weekly observations were recorded from 5 randomly selected plants. With a view to study the impact of different abiotic factors on pest incidence, a simple correlation between population of pest and abiotic factors was worked out using Statistical Package for the Social Sciences (SPSS 16.0) software.

\section{Results and Discussion}

Pooled data (2014 and 2015) on the seasonal incidence of $H$. armigera are presented in table 1 and figure 1 . This reveals that $H$. armigera population (1.17 larvae plant ${ }^{-1}$ ) was observed from the $7^{\text {th }}$ standard week, when mean maximum, minimum temperature, mean relative humidity (morning and evening) and rainfall were 20.85 and $7.85^{\circ} \mathrm{C}, 88.50$ and 55.00 per cent and $5.80 \mathrm{~mm}$, respectively. The larval population was to be increasing gradually with some fluctuations till $10^{\text {th }}$ standard week recording a population of 6.49 larvae per plant, when mean maximum and minimum temperature, mean relative humidity (morning and evening) and rainfall were 21.40 and $10.00^{\circ} \mathrm{C}, 90.00$ and 60.50 per cent and $34.10 \mathrm{~mm}$, respectively.

Thereafter, the $H$. armigera larvae population increased with some fluctuations till $15^{\text {th }}$ standard week (12.03 larvae plant ${ }^{-1}$ ) reaching its peak, when mean maximum and minimum temperature, mean relative humidity (morning and evening) and rainfall were 30.50 and $14.85^{\circ} \mathrm{C}, 75.00$ and 42.50 per cent and 0.00 $\mathrm{mm}$, respectively. The pod borer population thereafter decreased till $18^{\text {th }}$ standard week (2.01 larvae plant ${ }^{-1}$ ), when mean maximum and minimum temperature, mean relative humidity (morning and evening) and rainfall were 35.80 and $18.60^{\circ} \mathrm{C}, 65.50$ and 32.50 per cent and $5.75 \mathrm{~mm}$, respectively.

The results are in agreement with Shah and Shahzad (2005) who reported that population of $H$. armigera was low during $49^{\text {th }}$ to $6^{\text {th }}$ standard weeks but increased from $7^{\text {th }}$ standard week onwards and declined again during $14^{\text {th }}$ standard week. Similarly, Singh and Ali (2006) also reported two peaks in the larval population of $H$. armigera throughout the crop season, first from $46^{\text {th }}$ to $49^{\text {th }}$ and second from $5^{\text {th }}$ to $13^{\text {th }}$ standard weeks, which is in line with our results. Reddy et al., (2009) also reported that the incidence of $H$. armigera commenced from second week of February with 0.05 mean larval population/ plant. The larval populations started increasing and reached its maximum of 12.97 mean larva / plant during $4^{\text {th }}$ week of March $\left(12^{\text {th }}\right.$ standard week). 
Table.1 Population dynamics of Helicoverpa armigera on marigold (pooled)

\begin{tabular}{|c|c|c|c|c|c|c|}
\hline \multirow{3}{*}{ Standard week } & \multirow{3}{*}{$\begin{array}{c}\text { *Mean Helicoverpa } \\
\text { larval population/plant }\end{array}$} & \multicolumn{5}{|c|}{ Meteorological Parameters } \\
\hline & & \multicolumn{2}{|c|}{ Temperature $\left({ }^{\circ} \mathrm{C}\right)$} & \multicolumn{2}{|c|}{ Relative Humidity (\%) } & \multirow{2}{*}{ Rainfall (mm) } \\
\hline & & Maximum & Minimum & Morning & Evening & \\
\hline 7 & 1.17 & 20.85 & 7.85 & 88.50 & 55.00 & 5.80 \\
\hline 8 & 0.86 & 22.10 & 10.00 & 91.00 & 61.50 & 27.65 \\
\hline 9 & 2.82 & 19.90 & 9.40 & 90.00 & 60.00 & 59.60 \\
\hline 10 & 6.49 & 21.40 & 10.00 & 90.00 & 60.50 & 34.10 \\
\hline 11 & 2.97 & 24.10 & 11.20 & 87.00 & 57.50 & 72.90 \\
\hline 12 & 6.14 & 26.70 & 13.00 & 84.50 & 58.00 & 6.70 \\
\hline 13 & 5.70 & 26.65 & 14.20 & 85.00 & 58.00 & 51.20 \\
\hline 14 & 6.61 & 25.30 & 14.30 & 83.50 & 55.50 & 65.75 \\
\hline 15 & 12.03 & 30.55 & 14.85 & 75.00 & 42.50 & 0.00 \\
\hline 16 & 7.74 & 30.35 & 15.95 & 79.00 & 45.00 & 26.50 \\
\hline 17 & 5.67 & 35.45 & 18.20 & 66.50 & 45.00 & 0.00 \\
\hline 18 & 2.01 & 35.80 & 18.60 & 65.50 & 32.50 & 5.75 \\
\hline Range & 0.86-12.30 & $19.90-35.80$ & $7.85-18.60$ & $65.50-91.00$ & $32.50-61.50$ & $0.00-72.90$ \\
\hline Mean & 5.02 & 26.60 & 13.13 & 82.13 & 52.58 & 29.66 \\
\hline $\operatorname{S.Em}( \pm)$ & 0.93 & 1.57 & 1.01 & 2.56 & 2.63 & 7.78 \\
\hline
\end{tabular}

*Mean of five plants 
Table. 2 Correlation coefficients and regression model between Pod borer population and abiotic factors

\begin{tabular}{|c|c|}
\hline \multirow{2}{*}{ Characters } & 'r' values \\
\cline { 2 - 2 } & Pooled \\
\hline $\mathbf{X}_{\mathbf{1}}$ & $0.349^{* *}$ \\
\hline $\mathbf{X}_{\mathbf{2}}$ & 0.404 \\
\hline $\mathbf{X}_{\mathbf{3}}$ & $-0.284^{* *}$ \\
\hline $\mathbf{X}_{\mathbf{4}}$ & -0.256 \\
\hline $\mathbf{X}_{\mathbf{5}}$ & -0.174 \\
\hline Regression Model & $\mathrm{Y}=-20.580-0.678 \mathrm{X}_{1}+1.807 \mathrm{X}_{2}+0.314 \mathrm{X}_{3}-0.080 \mathrm{X}_{4}-0.055 \mathrm{X}_{5}\left(\mathrm{R}^{2}=0.286\right)$ \\
\hline
\end{tabular}

$* *$ Correlation is significant at 0.01 level, $*$ Correlation is significant at 0.05 level

Where, $\mathrm{Y}=$ Mean pod borer population; $\mathrm{X}_{1}=$ Maximum temperature $\left({ }^{\circ} \mathrm{C}\right) ; \mathrm{X}_{2}=$ Minimum temperature $\left({ }^{\circ} \mathrm{C}\right) ; \mathrm{X}_{3}=$ Mean relative humidity morning $(\%) ; \mathrm{X}_{4}=$ Mean relative humidity evening $(\%) ; \mathrm{X}_{5}=$ Rainfall $(\mathrm{mm})$

Fig.1 Population dynamics of pod borer, Helicoverpa armigera (pooled)

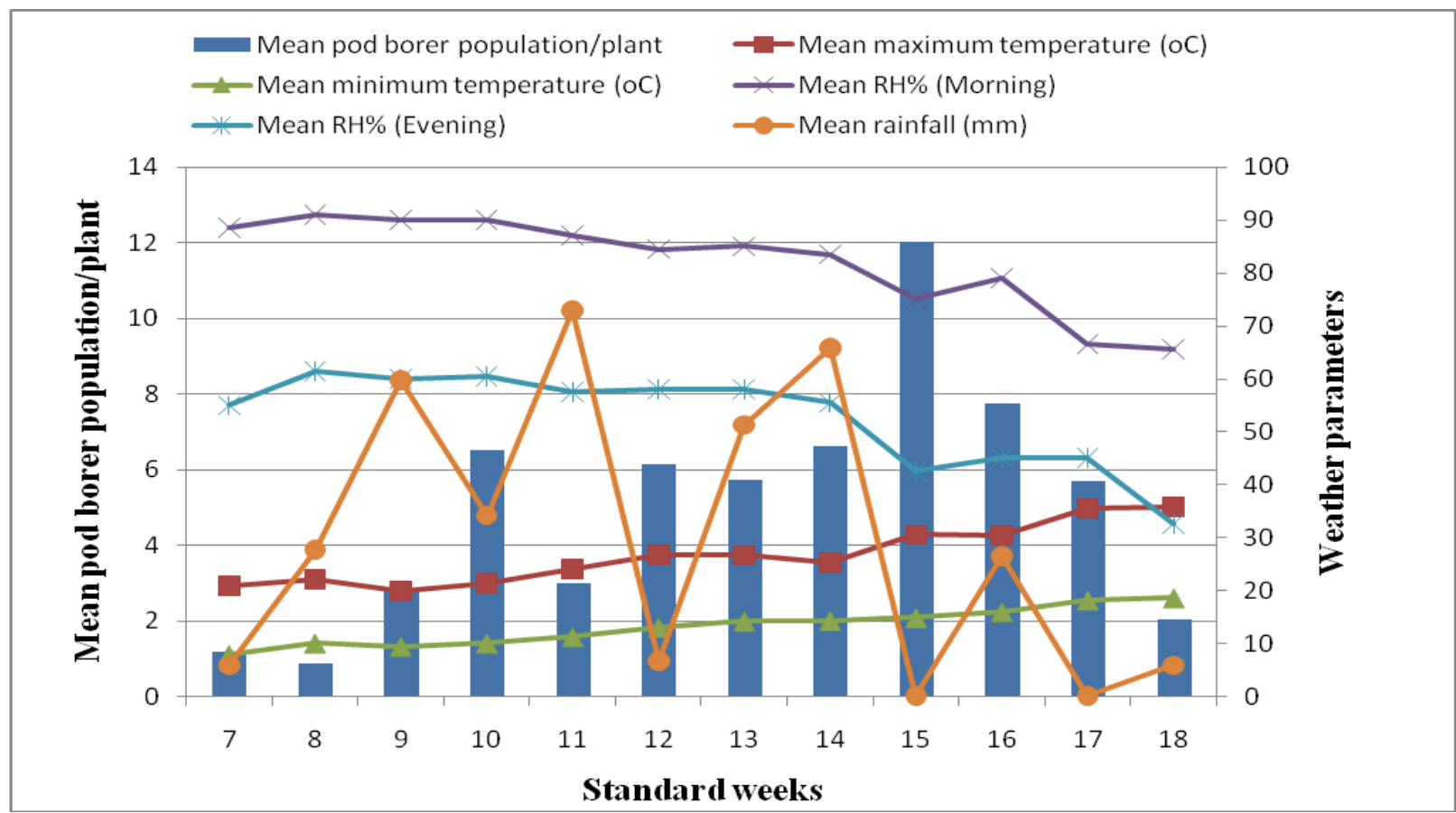

The studies are in line with Shinde et al., (2013) who reported that the larval population of $H$. armigera was recorded with two peak period during entire crop season, first from $17^{\text {th }}$ November to $10^{\text {th }}$ December $\left(47^{\text {th }}\right.$ to $50^{\text {th }}$ standard weeks) and second from $12^{\text {th }}$ March to $5^{\text {th }}$ April $\left(10^{\text {th }}\right.$ to $14^{\text {th }}$ standard weeks $)$ in year 2009-10 and first peak from $22^{\text {nd }}$ November to $13^{\text {th }}$ December $\left(47^{\text {th }}\right.$ to $50^{\text {th }}$ standard weeks) and second from $13^{\text {th }}$ March to $4^{\text {th }}$ April $\left(10^{\text {th }}\right.$ to $14^{\text {th }}$ standard weeks) during 2010-11.
The results on correlation studies revealed (Table 2) that mean maximum temperature had highly significant but positive effect on pod borer population with ' $\mathrm{r}$ ' value $\left(\mathrm{r}=0.349^{* *}\right)$. On the other hand mean relative humidity (morning) had highly but negative significant effect with ' $r$ ' value $(\mathrm{r}=-0.284 * *)$ on pod borer population, while as mean relative humidity (evening) and mean rainfall had negative effect on pod borer population with ' $\mathrm{r}$ ' values $(\mathrm{r}=$ 0.256 and $\mathrm{r}=-0.174)$. Mean minimum 
temperature had positive effect on the pod borer population $(\mathrm{r}=0.404)$. Regression studies for the effect of abiotic factors on the build-up of pod borer population were significantly influenced by weather factors and their contribution being 28.60 per cent. Nadaf and Kulkarni (2006) in a similar study reported that maximum temperature and minimum temperature had positive significant effect on $H$. armigera population. The results are in agreement with Reddy et al., (2009) who reported that the pod borer population had significantly positive correlation with both minimum and maximum temperature and the correlation coefficient being 0.71 and 0.82 , respectively. The correlation coefficient of morning and evening relative humidity was 0.66. Singh et al., (2010) and Pandey et al., (2012) reported negative correlation of rainfall and relative humidity with the pest activity, whereas maximum and minimum temperature, were positively correlated with pest activity, which is in line with our results.

\section{Acknowledgements}

The authors are thankful to the Professor and Head, Division of entomology, SKUASTJammu for providing facilities to carry out this work.

\section{References}

Adriana, D.B., Doru, P., Adriana, F.S., Lucica, M. and Radu, E.S. 2012. Heterosis studies for response to Aphis fabae attack in Calendula. Bull. UASVM. Hort., 69(1):4047.

Anonymous. 2016. Area and Production of Horticulture Crops - All India. National Horticulture Board. pp. 3.

Chatar, V.P., Raghvani, K.L., Joshi, M.D., Ghadge, S.M., Deshmukh, S.G. and Dalave,
S.K. 2010. Population dynamics of pod borer, Helicoverpa armigera (Hubner) infesting chickpea. Intl. J. Plant Prot., 3(1):65-67.

Krinski, D., and Godoy, A.F. 2015. First record of Helicoverpa armigera (Lepidoptera: Noctuidae) feeding on Plectranthus neochilus (Lamiales: Lamiaceae) in Brazil. Fla. Entomol, 98(4):1238-40.

Nadaf, A.M., and Kulkarni, K.A. 2006. Seasonal Incidence of the fruit borers, Helicoverpa armigera (Hubner) and Spodoptera litura Fabricius on chilli in Dharwad. Karnataka J. Agric. Sci., 19(3): 549-552.

Pandey, B.M., Tripati, M.K. and Lakshmi, V. 2012. Seasonal incidence of gram pod borer Helicoverpa armigera (hub.) on chickpea in Varanasi area. J. Exp. Zool., 15(2):667-669.

Reddy, A.V., Anandhi, P., Elamathi, S. and Verma, S. 2009. Seasonal occurrence of pulse pod borer Helicoverpa armigera (L.) on chick pea at eastern U.P. region. Agric. Sci. Digest, 29(2):60-62.

Shah, Z.A., and Shahzad, M.K. 2005. Population fluctuations with reference to different developmental stages of Helicoverpa armigera (Lepidoptera: noctuidae) on chickpea and their relationship with the environment. Intl. J. Agric. Biol., 7(1):9093.

Shinde, Y.A., Patel, B.R. and Mulekar, V.G. 2013. Seasonal incidence of gram caterpillar, Helicoverpa armigera (Hub.) in chickpea. Curr. Biotica, 7(1\&2):79-82.

Singh, K., Raju, S.V.S. and Singh, D.K. 2010. Population succession of tomato fruit borer (Helicoverpa armigera) on tomato (Lycopersicon esculentum Mill.) agroecosystem in eastern region of U. P. Legume Res., 33(2):148-149.

Singh, R., and Ali, S. 2006. Seasonal incidence of Helicoverpa armigera and Campoletis chlorideae on chickpea. Annl. Plant Prot. Sci., 14(1):234-235.

\section{How to cite this article:}

Suheel Ahmad Ganai, Hafeez Ahmad, Devinder Sharma, Nadeya Khaliq, Sonika Sharma, Ramandeep Kaur and Thanlass Norboo. 2017. Effect of Abiotic Factors on the Populations of Pod Borer, Helicoverpa armigera (Hubner) on Marigold, Tagetes erecta in Jammu. Int.J.Curr.Microbiol.App.Sci. 6(9): 181-185. doi: https://doi.org/10.20546/ijcmas.2017.609.023 